\title{
HEPATICS FROM ROVNO AMBER (UKRAINE), 2. ACROLEJEUNEA UCRAINICA SP. NOV.
}

\section{ПЕЧЁНОЧНИКИ ИЗ РОВЕНСКОГО ЯНТАРЯ (УКРАИНА), 2. ACROLEJEUNEA UCRAINICA SP. NOV.}

\author{
YURIY S. MAMONTOV ${ }^{1,2}$, JOCHEN HEINRICHS ${ }^{3}$, ALFONS SCHÄFER-VERWIMP ${ }^{4}$ \\ MiCHAEL S. IGNATOV ${ }^{5} \&$ EVGENY E. PERKOVSKY ${ }^{6}$ \\ ЮРИЙ С. МАМОНТОВ ${ }^{1,2}$, ЙОХЕН ХАЙНРИКС ${ }^{3}$, АЛЬФОНС ШЭФЕР-ФЕРВИМП ${ }^{4}$, \\ МИХАИЛ С. ИГНАТОВ ${ }^{5}$, ЕВГЕНИЙ Э. ПЕРКОВСКИЙ ${ }^{6}$
}

Abstract

A fossil of Lejeuneaceae subfam. Ptychantoideae is described based on an inclusion in Late Eocene Rovno amber. The unbranched sterile shoot has obliquely spreading, squarrose, complicate-bilobed leaves with rounded lobes and some dorsal lobe margins curved backwards as well as suberect upper shoot sectors with small leaves possibly serving for vegetative distribution. Based on morphological similarities the fossil is assigned to the extant genus Acrolejeunea, as A. ucrainica Mamontov, Heinrichs et Schäf.-Verw. sp. nov., being the first fossil of this genus and the third liverwort from Rovno amber.

Резюме

Ископаемый вид печёночников семейства Lejeuneaceae (подсемейство Ptychantoideae) описан из ровенского янтаря, относящегося к позднему эоцену. Неветвящийся стерильный побег характеризуется косо отстоящими, растопыренными листьями с частично завёрнутыми внутрь верхушками дорсальных лопастей, а также наличием отогнутой верхней части побега с более мелкими листьями, вероятно, служившими для вегетативного размножения. На основании морфологического сходства растение отнесено к современному роду Acrolejeunea и описано как новый для науки вид A. ucrainica Mamontov, Heinrichs et Schäf.-Verw. sp. nov. Таким образом, впервые описан ископаемый вид рода Acrolejeunea. Данная находка - третий вид печёночников для эоценовой флоры Ровно.

KEYWORDS: fossil, hepatics, Ptychanthoideae, Lejeuneaceae, amber, Rovno, Ukraine, Tertiary, Eocene

\section{INTRODUCTION}

Baltic amber is the best-known source for Late Eocene bryophyte inclusions. As yet, some 23 liverworts (Grolle $\&$ Meister, 2004) and 60 mosses (Frahm, 2010) have been described, allowing for a comparison with the extant diversity and insights into European palaeoecosystems.

In contrast, little attention has been given to bryophyte inclusions in contemporaneous amber from Rovno region, Ukraine. Only recently, two liverworts (Frullania varians Casp. and F. ucrainica Konstant. \& Ignatov, Konstantinova et al., 2012) and ten mosses (Ignatov \& Perkovsky, 2011) were recognized, indicating that this amber could be a rich source of bryophytes of the Paleogene of Eastern Europe. Indeed, subsequent study of Rovno amber revealed new inclusions, of which one is described in the present paper. This inclusion belongs to Lejeuneaceae rather than
Frullaniaceae due to the presence of a leaf lobule with a long keel. The reniform underleaves and broad ventral merophytes point to Lejeuneaceae subfam. Ptychanthoideae (Gradstein, 2013). This subfamily has been recognized in various Cenozoic ambers. Eocene Baltic amber includes the Ptychanthoideae genera Spruceanthus Verd. and Mastigolejeunea (Spruce) Schiffn.; the latter is also present in Late Eocene Bitterfeld amber (Grolle \& Meister, 2004). The Ptychanthoideae genera Archilejeunea (Spruce) Schiffn., Bryopteris (Nees) Lindenb., Lopholejeunea (Spruce) Schiffn., Marchesinia Gray, and Mastigolejeunea have been reported from Middle Miocene Dominican amber (Grolle, 1984a, 1993; Gradstein, 1993).

The new inclusion has obliquely spreading, squarrose, complicate-bilobed leaves with rounded lobes and some dorsal lobe margins curved backwards as well as

1 -Polar-alpine botanical garden-institute of Kola SC RAS, 184236 Kirovsk-6, Russia; e-mail: yur-mamontov@yandex.ru

2 - Institute of North Ecological Problems, Kola Science Centre of RAS, 18a Fersmana St., Apatity, Murmansk Province, 184209 Russia

3 - Systematic Botany and Mycology, Ludwig Maximilians University Munich, Menzinger Str. 67, 80638 Munich, Germany; email: jheinrichs@lmu.de

4 -Mittlere Letten 11, 88634 Herdwangen-Schönach, Germany; e-mail: moos.alfons@kabelbw.de

5 _ Main Botanical Garden, Russian Academy of Sciences, Botanicheskaya 4, Moscow 127276 Russia, e-mail: misha ignatov@list.ru

${ }^{6}$ - Schmalhausen Institute of Zoology of the Ukrainian National Academy of Sciences, B. Khmelnitsky str., 15, Kiev 01-106, Ukraine; e-mail: perkovsk@gmail.com 

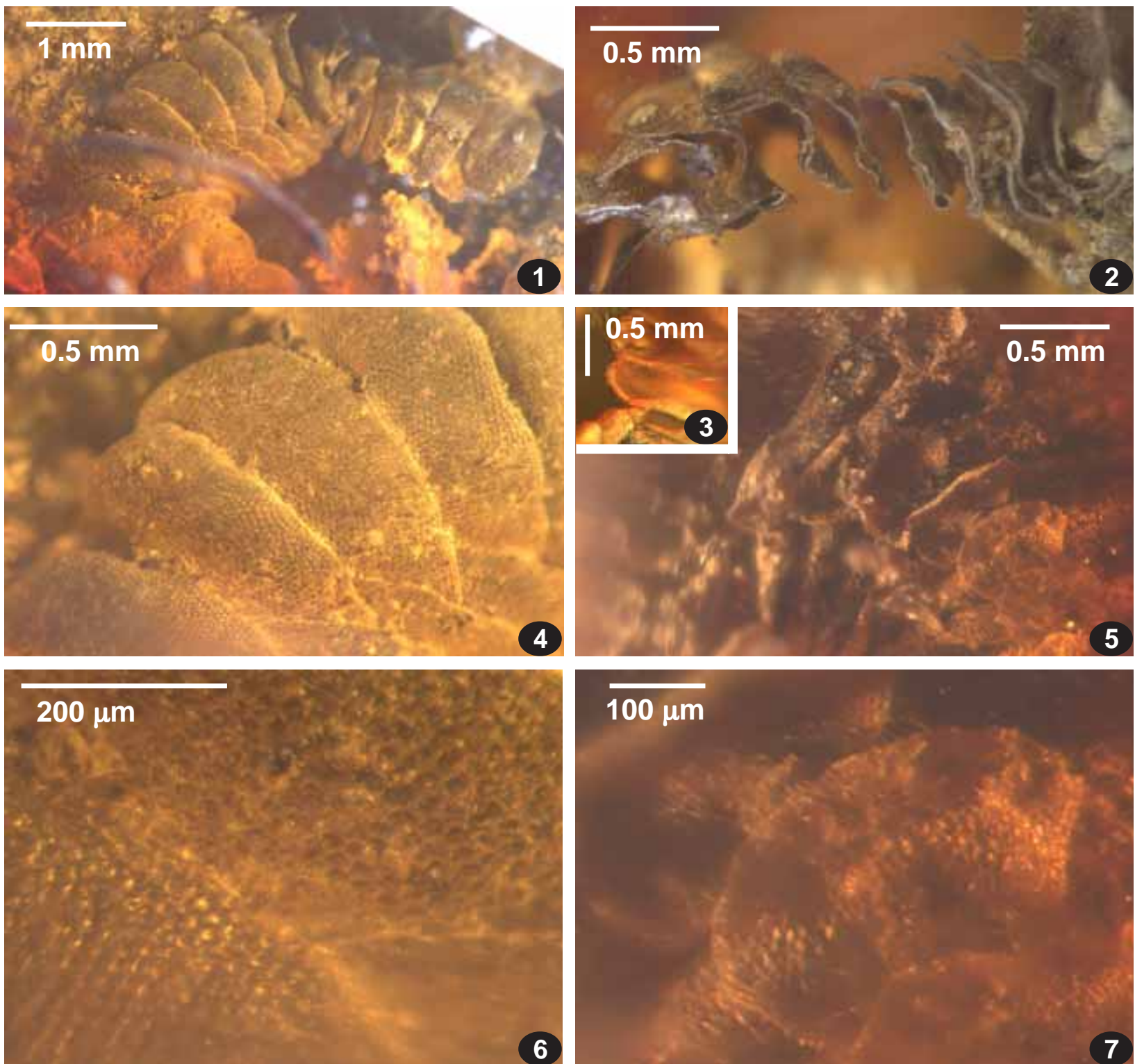

$100 \mu \mathrm{m}$
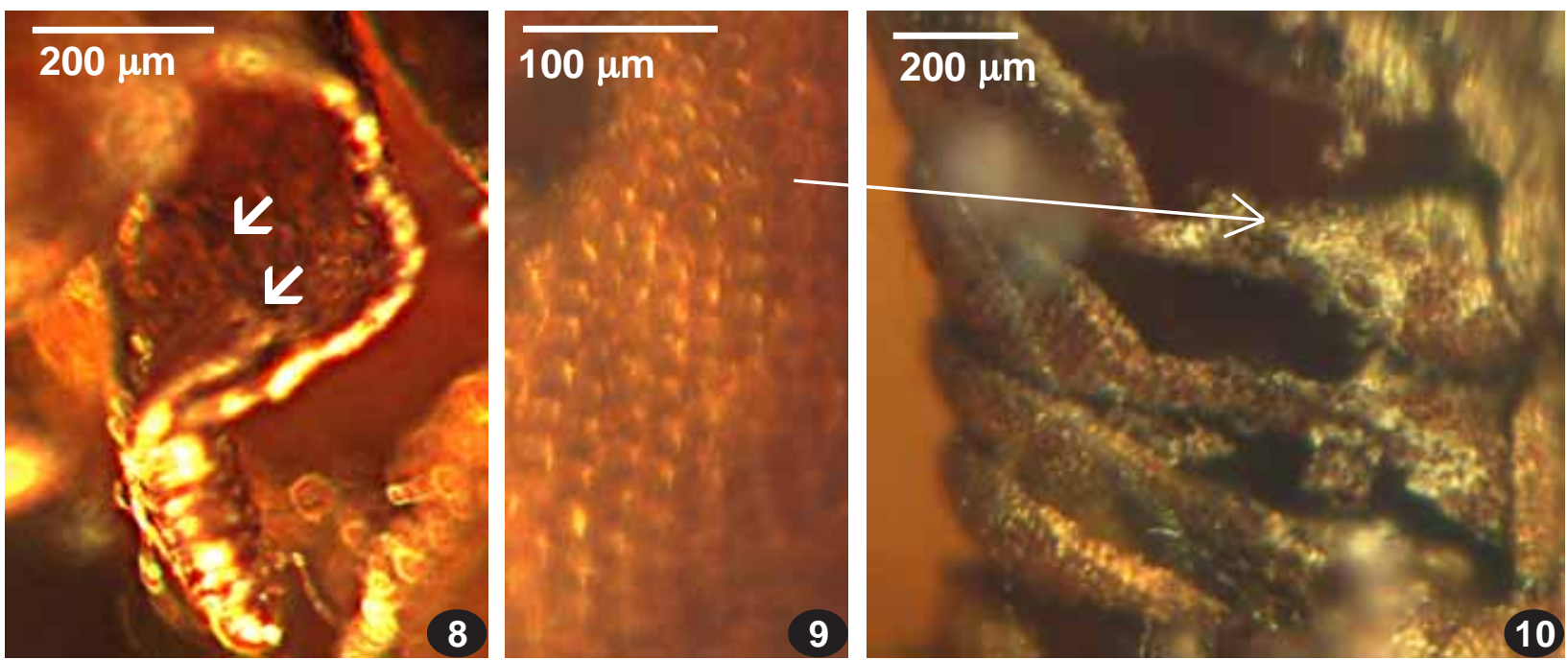

Figs. 1-10. Acrolejeunea ucrainica sp. nov. (from SIZK-K-10052F): 1 - habit, dorsal view; 2 - habit, lateral view; 3 - leaves from distal part of shoot (ventral view), showing involute margin; $4 \& 6$ - lobe areolation of leaves from middle part of shoot, dorsal view; 5 \& 7 - amphigastria, ventral view; 8 - damaged leaf (lateral view), showing dentate margin of lobule (arrowheads point to teeth); 9 - cells from proximal part of lobule close to keel, venral view; 10 - leaf in vental view, showing keel areas. 
suberect upper shoot sectors with small leaves serving possibly for vegetative distribution. These characters do not correspond to any of the above genera but point to Acrolejeunea (Spruce) Schiffn.

Here, we describe the new Rovno amber inclusion as Acrolejeunea ucrainica, sp. nov.

\section{MATERIALS AND METHODS}

The amber piece is part of the Rovno amber collection of the Schmalhausen Institute of Zoology in Kiev (SIZK-K-10052F). According to recent studies (Kosmowska-Ceranowicz, 1999; Perkovsky et al., 2003, 2007, 2010; Aleksandrova \& Zaporozhets, 2008a, b), it shares its age with Baltic amber, hence being Late Eocene in age.

The fossil liverwort was photographed using a stereomicroscope Olympus SZX16 with a 1.6× objective lens, equipped with an Infinity 4 digital camera. To better illustrate the three-dimensional inclusion, a number of images were combined from 5-15 optical sections using the software package HeliconFocus 4.50 (Kozub et al., 2008). Additional measurements were conducted using a compound microscope Carl Zeiss Axiolab with ocular rulerand with $4 \times$ and $10 \times$ objective magnification.

\section{TAXONOMY}

Genus Acrolejeunea (extant, subfamily Ptychanthoideae of family Lejeuneaceae)

Description. Leafy liverwort. Plants medium-sized to robust (up to $2.4 \mathrm{~mm}$ broad and to $5 \mathrm{~cm} \mathrm{long).} \mathrm{Shoots} \mathrm{prostrate}$ to ascending, very sparsely irregularly branched; branching of Lejeunea-type, rarely of Frullaria-type; subfloral innovations absent. Leaves incubously inserted, imbricate, when moist often squarrose, when dry becoming convolute and suberect. Lobes oblong-ovate, entire-margined, rounded to obtuse, base cordate to auriculate. Lobules ovate, 0.4-0.65 the lobe length, the portion adjacent to keel inflated; free lobule margin flat, appressed to lobe, bearing (1-)3-8(-9) small teeth. Keel moderately to strongly arched. Cells elongate-hexagonal, thin-walled, with usually large sinuous trigones; intermediate thickenings present; the cell lumen usually clearly sinuate-undulate. Cells regularly oriented in curving rows; ocelli absent. Underleaves contiguous to imbricate, entire, reniform to broadly obdeltoid, usually clearly wider than long; the line of insertion weakly to moderately acroscopically arched. Asexual reproduction often present, via caducous leaves of abbreviated, specialised erect shoot apices. Plants di-, aut-, or paroecious. Female inflorescences terminal, on elongated branches, without true subfloral innovations. Perianths normally somewhat dorsiventrally compressed and plicate with 4-10 smooth keels, contracted at apex into a short beak; the keels never sharp or dentate. Male bracts not sharply differentiated from leaves, in 6-18 (to 50) pairs, becoming intercalary on main shoots.

Type species: Acrolejeunea aulacophora (Mont.) Schiffn. [= Ptychocoleus aulacophorus (Mont.) Trevis.]

The pantropical genus includes 15 extant species (Gradstein, 1975).

Fossil record: Hitherto no fossils known.
Acrolejeunea ucrainica Mamontov, Heinrichs et Schaf.-Verw., sp. nov.

HOLOTYPE: Klesov. Rovno amber. Late Eocene. SIZK-K-10052F (Figs 1-10). Specimen found in transparent, partly contaminated amber piece (\#2-748, 18.5 g, 48×33×16 мм), syninclusion K-9651: male Theridiidae (Aranei).

Description: Sterile, unbranched, creeping shoot, ca. 6 $\mathrm{mm}$ long and up to $2 \mathrm{~mm}$ wide. Stem robust, visible only between some underleaves which are bent downwards (Fig. 5), with incubous foliation. Leaves alternating, imbricate, with U-shaped insertion, dorsally deeply interlocking and covering the whole stem (Figs. 1, 4). Lobes concave in ventral view, $0.70-1.35 \mathrm{~mm}$ long and $0.5-0.9 \mathrm{~mm}$ wide, asymetrically ovate-oblong, margins entire, reflexed to ventral side; dorsal margin curved outwards, apex rounded, broadly incurved towards the ventral side of the stem; ventral margin sinuate, free ventral margin taking ca. $0.50-0.66$ of lobe with widely curved transition to keel (Fig. 10). Cells of lobes regularly arranged in curving rows (Figs. 4, 6), hexagonal; cell walls thin, not sinuate, trigones large, cordate, not sinuate; intermediate thickenings present. Median lobe cells 15-18 $\mu \mathrm{m}$ wide, 20-27 $\mu \mathrm{m}$ long, marginal cells subisodiametric, 18-23 $\mu \mathrm{m}$ in diam., similar to median leaf cells in shape and size but overall slightly less elongate. Cuticle smooth throughout. Larger leaf cells indicating ocelli not observed. Keel at an angle of $15-45^{\circ}, 0.3(-0.5)$ the leaf lobe length, moderately arched, at base convex; the rear narrowly rounded distally, towards base becoming broadly rounded. Lobule large, widest near apex, 0.35-0.44 $\mathrm{mm}$ long and $0.25-0.37 \mathrm{~mm}$ wide; the portion adjacent to keel inflated; free margin flat, appressed to lobe, not clearly visible throughout but at least with two indistinct teeth (Fig. 10). Underleaves with somewhat inverted U-shaped insertion, weakly imbricate to slightly distant, suborbicular to reniform, entire-margined, 377-485 $\mu \mathrm{m}$ wide, 250-320 $\mu \mathrm{m}$ long, ca. 1.5-1.6× wider than long, about 3.2-5.4 times wider than stem, not decurrent, with rounded to almost cordate base, touching the stem or strongly reflexed to ventral side (Figs. 5, 7). Lamina concave or convex, without distinct area of rhizoid initials. Upper part of shoot (ca. 1/3 of the whole length) abruptly bent upwards, suberect, with smaller leaves, some of them detached and possibly serving for vegetative distribution.

The classification of amber inclusions is often hampered by their incomplete preservation and the way they are embedded in the fossil resin. This holds especially true for the hitherto known liverworts from Rovno amber, representing Lejeuneaceae and Frullaniaceae. Members of these families often grow attached to bark. If they are embedded together with parts of the substratum, their ventral sides are at best indistinctly visible. However, the ventral structures, i.e. lobuli, styli and underleaves, are often essential for a reliable identification; lack of information on these structures usually allows a classification only to the level of family or order.

Fortunately both the dorsal and the ventral sides of the new inclusion could be investigated, indicating the pres- 
ence of a representative of Lejeuneaceae subfam. Ptychanthoideae. Although fertile structures are lacking and not all details of the sterile gametophyte were clearly visible, the morphology of the fossil allowed for rejecting an affiliation to other Ptychanthoideae species known from Eocene ambers, namely Mastigolejeunea contorta (Göpp. \& Berendt) Gradst. \& Grolle and Spruceanthus polonicus Grolle (Grolle $\&$ Meister, 2004). The subvertically positioned, squarrose leaves resemble extant representatives of Acrolejeunea, as do the dorsal leaf margins which are curved backwards (Figs. $2,8)$. The suberect upper shoot sector with small leaves is also typical for Acrolejeunea. Further support comes from the arrangement of the lobe cells in curved rows which parallel the dorsal lobe margin (Figs. 4, 6), and the presence of cordate trigones as well as intermediate thickenings.

Molecular data indicate a Cretaceous age of Acrolejeunea (Wilson et al., 2007) and hence do not contradict our interpretation. Currently only a few accessions of Acrolejeunea have been included in molecular analyses, hampering a detailed reconstruction of the evolutionary history of this genus. According to available data, the crown group of $A c$ rolejeunea started to diversify in the Paleogene. Hence, the Eocene amber inclusion could represent either a member of the genus' stem lineage or of its crown group.

The Eocene age of the fossil renders the presence of an extant species unlikely, and the morphology of the species likewise differs from the extant diversity (Gradstein, 1975; Gradstein et al., 2002; Renner, 2013). A detailed comparison with the extant species is hampered by the lack of knowledge on the exact constitution of the lobule, especially the number of its teeth. According to available evidence, the amber inclusion resembles the Paleotropical A. pycnoclada (Tayl.) Schiffn. but is more robust than this species, and has squarrose leaves. More fossils of Acrolejeunea ucrainica are necessary to scrutinize its present classification, and to amend the diagnosis.

Acrolejeunea ucrainica is the first representative of Lejeuneaceae described from Late Eocene Rovno amber, which already yielded Frullania ucrainica Konstant. \& Ignatov and $F$. varians Casp. Only the latter species has so far been recognized in contemporaneous Baltic amber. According to current evidence, both Eocenic amber deposits are dominated by inclusions of Frullania and Lejeuneaceae but differ with regard to species composition. A similar situation is seen in the amber liverwort floras of the Middle Miocene of the Dominican Republic (Reiner-Drehwald et al., 2010) and Mexico (Grolle, 1984b), however, these amber floras were dominated by Lejeuneaceae rather than by Frullania, which hitherto has only rarely been observed in Dominican amber (Heinrichs \& Schmidt, 2010).

It remains to be seen if these trends are confirmed by future studies on Cenozoic ambers, which hopefully will lead to further finds of liverwort inclusions. These inclusions will allow for a reconstruction of palaeocommunities of bryophytes colonizing either bark or the floor of past amber forests, and provide new insights into biogeographical patterns.

\section{ACKNOWLEDGEMENTS}

We are grateful to A.P. Vlaskin (SIZK) for specimen preparation and to K.Yu. Eskov for spider identification. The work was partly suported by RFBR 13-04-90728.

\section{LITERATURE CITED}

ALEKSANDROVA, G.N. \& N.I. ZAPOROZHETS 2008a. Palynological characteristics of Upper Cretaceous and Paleogene deposits on the west of the Sambian Peninsula (Kaliningrad region), Part 1. - Stratig. Geol. Corr. 16: 295-316.

ALEKSANDROVA, G.N. \& N.I. ZAPOROZHETS 2008b. Palynological characteristics of Upper Cretaceous and Paleogene deposits on the west of the Sambian Peninsula (Kaliningrad region), Part 2. - Strat. Geol. Corr. 16: 528-539.

FRAHM, J.-P. 2006. Neue Moosfunde aus baltischem Bernstein. - Limprichtia 29: 119-129.

FRAHM, J.-P. 2010. Die Laubmoosflora des baltischen Bernsteinwaldes. - Weissdorn, Jena, 91 pp.

GRADSTEIN, S.R. 1975. A taxonomic monograph of the genus Acrolejeunea (Hepaticae) with an arrangement of genera of Ptychanthoideae. - Bryophyt. Biblioth. 4: 1-216.

GRADSTEIN, S.R. 1993. New fossil Hepaticae preserved in amber of the Dominican Republic. - Nova Hedwigia 57: 353-374.

GRADSTEIN, S.R. 2013. A classification of Lejeuneaceae based on molecular and morphological evidence. - Phytotaxa 100: 6-20.

GRADSTEIN, S. R., X.-L. HE, S. PIIPPO \& M. MIZUTANI 2002. Bryophyte flora of the Huon Peninsula, Papua New Guinea. LXVIII. Lejeuneaceae subfamily Ptychanthoideae (Hepaticae). - Acta Bot. Fenn. 174: 1-88.

GROLLE, R. 1984a. Bryopteris and Cyclolejeunea fossils in the Dominican amber. - J. Hattori Bot. Lab. 56: 271-280.

GROLLE, R. 1984b. Lejeunea palaeomexicana n. sp., das erste Moos aus Mexikanischem Bernstein. - Stuttgarter Beitr. Naturk., B 108: 1-7.

GROLLE, R. 1993. Bryopteris bispinosa sp. nov. (Lejeuneaceae), another liverwort from Dominican amber. - J. Hattori Bot. Lab. 74: 71-76.

GROLLE, R. \& K. MEISTER 2004. The liverworts in Baltic and Bitterfeld amber. - Weissdorn, Jena. 91 pp.

HEINRICHS, J. \& A. R. SCHMIDT 2010. An inclusion of Frullania subgen. Diastaloba s.l. (Frullaniaceae, Porellales) in Dominican amber. - Trop. Bryol. 31: 91-94.

IGNATOV, M.S. \& E.E. PERKOVSKY 2011. Mosses from Rovno amber (Ukraine). - Arctoa 20: 1-18.

KONSTANTINOVA, N.A., M.S. IGNATOV \& E.E. PERKOVSKY 2012. Hepatics from Rovno amber (Ukraine). - Arctoa 21: 265-271.

KOSMOWSKA-CERANOWICZ, B 1999. Succinite and some other fossil resins in Poland and Europe (deposits, finds, features and differences in IRS). - Estud.l Mus. Cienc. Nat. Alava 14(2): 73-117.

KOZUB, D., V. KHMELIK, YU. SHAPOVAL, V. CHENTSOV, S. YATSENKO, B. LITOVCHENKO \& V. STARYKH 2008. Helicon Focus Software. http://www.heliconsoft.com

PERKOVSKY, E.E., V.Yu. ZOSIMOVICH \& A.P. VLASKIN 2003. Rovno amber insects: first results of analysis. - Russ. Entomol. J. 12(2): 119-126.

PERKOVSKY, E.E., A.P. RASNITSYN, A.P. VLASKIN \& M.V. TARASCHUK 2007. A comparative analysis of Baltic and Rovno amber arthropod faunas: perspective samples. - Afr. Invert. 48: 229-245.

PERKOVSKY, E.E., V.Yu. ZOSIMOVICH \& A.P. VLASKIN 2010. Rovno amber. - In: Penney, D. (ed.) Biodiversity of fossils in amber from the major world deposits. Siri Sci. Press, Manchester: 116-136.

REINER-DREHWALD, M.E., A.R. SCHMIDT \& J. HEINRICHS 2012. The genus Lejeunea in Miocene amber from the Dominican Republic. - Cryptog. Bryol. 33: 33-38.

RENNER, M.A.M. 2013. A new subspecies of Acrolejeunea arcuata, and notes on typification, synonymy, and distribution of other Australasian Lejeuneaceae. - Phytotaxa 83: 39-53.

WILSON, R., J. HEINRICHS, J. HENTSCHEL, S.R. GRADSTEIN \& H. SCHNEIDER 2007. Steady diversification of derived liverworts under Tertiary climatic fluctuations. - Biol. Lett. 3: 566-569. 